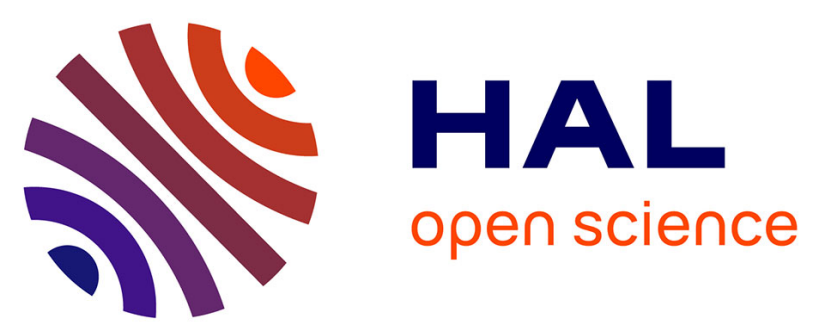

\title{
Evidence for Social and Cultural Change in Central Vanuatu Between 3000 and 2000 BP: Comparing Funerary and Dietary Patterns of the First and Later Generations at Teouma, Efate
}

Frédérique Valentin, Estelle Herrscher, Stuart Bedford, Matthew Spriggs, Hallie Buckley

\section{To cite this version:}

Frédérique Valentin, Estelle Herrscher, Stuart Bedford, Matthew Spriggs, Hallie Buckley. Evidence for Social and Cultural Change in Central Vanuatu Between 3000 and 2000 BP: Comparing Funerary and Dietary Patterns of the First and Later Generations at Teouma, Efate. Journal of Island and Coastal Archaeology, 2014, 93, pp.381 - 399. 10.1080/15564894.2014.921958 . hal-01411008

\author{
HAL Id: hal-01411008 \\ https://hal.science/hal-01411008
}

Submitted on 6 Dec 2016

HAL is a multi-disciplinary open access archive for the deposit and dissemination of scientific research documents, whether they are published or not. The documents may come from teaching and research institutions in France or abroad, or from public or private research centers.
L'archive ouverte pluridisciplinaire $\mathbf{H A L}$, est destinée au dépôt et à la diffusion de documents scientifiques de niveau recherche, publiés ou non, émanant des établissements d'enseignement et de recherche français ou étrangers, des laboratoires publics ou privés. 
This article was downloaded by: [Frederique Valentin]

On: 11 November 2014, At: 00:10

Publisher: Routledge

Informa Ltd Registered in England and Wales Registered Number: 1072954 Registered office: Mortimer House, 37-41 Mortimer Street, London W1T 3J H, UK

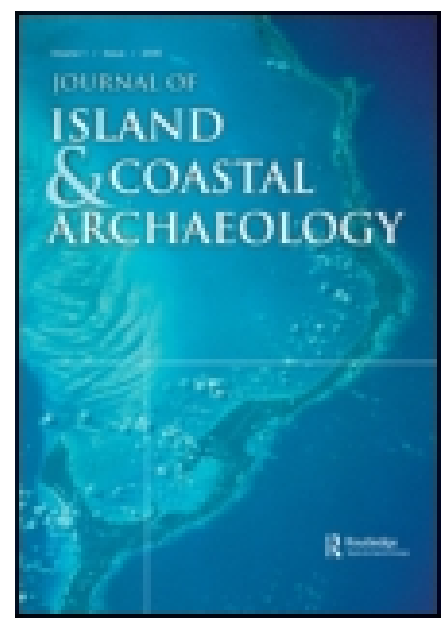

\section{The J ournal of Island and Coastal Archaeology}

Publication details, including instructions for authors and subscription information:

http:// www. tandfonline.com/loi/ uica20

\section{Evidence for Social and Cultural Change in Central Vanuatu Between 3000 and 2000 BP: Comparing Funerary and Dietary Patterns of the First and Later Generations at Teouma, Efate}

Frédérique Valentin $^{a}$, Estelle Herrscher ${ }^{b}$, Stuart Bedford ${ }^{c}$, Matthew Spriggs $^{d} \&$ Hallie Buckley

a CNRS, ArScAn UMR 7041, Université Paris 1 Panthéon-Sorbonne, Paris Ouest-La Défense, Nanterre, France

${ }^{b}$ CNRS, Ministère de la Culture et de la Communication, LAMPEA UMR 7269, Aix Marseille Université, Aix-en-Provence, France

${ }^{c}$ College of Asia and the Pacific, Australian National University, Canberra, Australian Capital Territory, Australia

${ }^{\mathrm{d}}$ College of Arts and Social Sciences, Australian National University, Canberra, Australian Capital Territory, Australia

e Department of Anatomy, University of Otago, Dunedin, New Zealand

Published online: 06 Nov 2014.

To cite this article: Frédérique Valentin, Estelle Herrscher, Stuart Bedford, Matthew Spriggs \& Hallie Buckley (2014) Evidence for Social and Cultural Change in Central Vanuatu Between 3000 and 2000 BP: Comparing Funerary and Dietary Patterns of the First and Later Generations at Teouma, Efate, The J ournal of Island and Coastal Archaeology, 9:3, 381-399, DOI: 10.1080/ 15564894.2014.921958

To link to this article: http:// dx. doi.org/ 10.1080/ 15564894.2014.921958

\section{PLEASE SCROLL DOWN FOR ARTICLE}

Taylor \& Francis makes every effort to ensure the accuracy of all the information (the "Content") contained in the publications on our platform. However, Taylor \& Francis, our agents, and our licensors make no representations or warranties whatsoever as to the accuracy, completeness, or suitability for any purpose of the Content. Any opinions and views expressed in this publication are the opinions and views of the authors, and are not the views of or endorsed by Taylor \& Francis. The accuracy of the Content should not be relied upon and should be independently verified with primary sources 
of information. Taylor and Francis shall not be liable for any losses, actions, claims, proceedings, demands, costs, expenses, damages, and other liabilities whatsoever or howsoever caused arising directly or indirectly in connection with, in relation to or arising out of the use of the Content.

This article may be used for research, teaching, and private study purposes. Any substantial or systematic reproduction, redistribution, reselling, loan, sub-licensing, systematic supply, or distribution in any form to anyone is expressly forbidden. Terms \& Conditions of access and use can be found at http://www.tandfonline.com/page/termsand-conditions 


\section{Evidence for Social and Cultural Change in Central Vanuatu Between 3000 and 2000 BP: Comparing Funerary and Dietary Patterns of the First and Later Generations at Teouma, Efate}

Frédérique Valentin, ${ }^{1}$ Estelle Herrscher, ${ }^{2}$ Stuart Bedford, ${ }^{3}$ Matthew Spriggs, ${ }^{4}$ and Hallie Buckley ${ }^{5}$

${ }^{1}$ CNRS, ArScAn UMR 7041, Université Paris 1 Panthéon-Sorbonne,

Paris Ouest-La Défense, Nanterre, France

${ }^{2}$ CNRS, Ministère de la Culture et de la Communication, LAMPEA UMR 7269,

Aix Marseille Université, Aix-en-Provence, France

${ }^{3}$ College of Asia and the Pacific, Australian National University, Canberra, Australian Capital Territory, Australia

${ }^{4}$ College of Arts and Social Sciences, Australian National University, Canberra, Australian Capital Territory, Australia

${ }^{5}$ Department of Anatomy, University of Otago, Dunedin, New Zealand

ABSTRACT

In the southern Melanesian islands of Vanuatu, as in New Caledonia, Fiji, and West Polynesia, the archaeological record indicates significant shifts in aspects such as patterns of settlement and mobility, landscape use, and pottery production, some 500 years (2500 BP) after

Received 26 June 2013; accepted 9 March 2014.

Address correspondence to Frederique Valentin, CNRS, ArScAn UMR 7041, Université Paris 1 PanthéonSorbonne, Paris Ouest-La Défense, Maison René Ginouvès, 21 Allée de l'Université, Nanterre 92023, France. E-mail: frederique.valentin@mae.u-paris10.fr

Color versions of one or more of the figures in the article can be found online at http://www.tandfonline.com/uica. 


\begin{abstract}
initial colonization. The relatively uniform Lapita Cultural Complex, the first manifestation of buman activity on these islands, was transformed in each archipelago into various distinctive cultural entities. Using dietary ( $\delta^{13} C$ and $\delta^{15} N$ values measured in collagen) and mortuary data recorded in 43 Lapita and seven immediately Post-Lapita adult burials from the site of Teouma (Efate, Vanuatu), we demonstrate that these medium-term, transformative processes also affected the economic component of the social system as well as its symbolic and religious structures. Evolutionary change adapting to changing local conditions is envisioned as the likely dominant factor influencing this cultural trajectory, while environmental/climatic change, secondary migration, and internal social changes unrelated to adaptive processes could have interacted to produce the recorded patterns.
\end{abstract}

Keywords evolutionary change, funerary practices, isotopic dietary simulations, Lapita, Vanuatu

\section{INTRODUCTION}

The archaeological records of Vanuatu, as well as of New Caledonia, Fiji, and West Polynesia, indicate a significant shift in the patterns of mobility, environment use, settlement mode, and the production of pottery and other materials, by $2500 \mathrm{BP}$ (Clark and Anderson 2009; Kirch 2000). The relatively uniform Lapita Cultural Complex, marking the first human colonization of Remote Oceania (southeast Solomons to Samoa) around $3000 \mathrm{BP}$, transformed locally in each archipelago into distinct cultural entities (Bedford 2009; Clark and Anderson 2009; Sand 2010; Sand et al. 2011; Summerhayes 2007). Adaptation to changing local conditions and constraints is a favored primary factor seen as influencing the distinctive intra-archipelago cultural trajectories that occurred across the region after initial arrival (Bedford 2006; Bedford and Clark 2001; Clark and Anderson 2009; Kirch 1984, 2000; Reepmeyer and Clark 2010; Sand 2010; see also Anderson et al. 2006; Spriggs 1997, 2003, 2004). We revisit this proposition using mortuary and dietary data that are generally conservative and stable components of culture. Based on a sample of 50 burials from the site of Teouma on Efate in central Vanuatu, our study demonstrates major changes in food and funerary practices which, added to others in patterns of mobility, resource use, settlement, and artifact production, indicate a significant intergenerational shift in the social system by some 500 years after first settlement.

\section{DIACHRONIC CHANGES AT TEOUMA}

At the site of Teouma, on Efate in central Vanuatu, diachronic changes occur in various sets of human productions and activities (Bedford and Spriggs, 2007; Bedford et al. 2006, 2009, 2010). As indicated by analysis of the ceramic decorative techniques, pottery temper, and obsidian geochemical composition, the initially high level of human mobility declined over time (Bedford et al. 2009; Dickinson et al. 2013; Reepmeyer et al. 2011). Ceramic production changed from Lapita to Arapus (c. $2800 \mathrm{BP}$ ) and then to Erueti (c. 2800/2700-2300 BP) styles, with major changes in vessel form and decoration identified by 2500 BP (Bedford 2009). During the Lapita phase some $11 \%$ of pottery vessels analyzed at Teouma were imports from New Caledonia (8\%), and from northern Vanuatu (3\%) or even further afield (Dickinson et al. 2013). In subsequent phases such imports ceased entirely. Imported obsidian disappeared by $2800 \mathrm{BP}$ (although locally procured lithic material was used throughout the sequence) (Reepmeyer et al. 2011). Parallel changes in environment use are observed at Teouma as in other sites in Vanuatu, with an introduction of domesticates and commensal species (pig, chicken, and 
rat) from the earliest Lapita phase (Bedford et al. 2009; Storey et al. 2010) and a decline in marine and local terrestrial fauna, including extinction of giant land tortoises (?Meiolania damelipi), land crocodiles (Mekosuchus kalpokasi) and many bird species from Lapita through to the Erueti periods (Bedford 2006; Mead et al. 2002; Steadman 2006; White et al. 2010).

Over time Teouma also displays very distinctive changes in settlement pattern (Bedford et al. 2009, 2010). During the Lapita phase at c. $2900 \mathrm{BP}$ the site initially comprised a cemetery and an adjacent contemporary settlement evidenced by a midden deposit that respects the boundary of the cemetery (in Areas 2 and 3). Within a few hundred years the settlement expanded across the cemetery area which was buried by the deposition of some $50 \mathrm{~cm}$ or more of midden associated with the Arapus and Early Erueti phases, dating to c. 2800-2500 BP. Over time the settlement expanded to cover a much larger area and Erueti period burials, c. $2400 \mathrm{BP}$, were interred some $70 \mathrm{~m}$ away to the south and east (Area $7 \mathrm{C}$ and Trench 3) of the Lapita cemetery.

\section{Material}

Since 2004 a total of 79 mortuary contexts have been identified in three localities of the Teouma site (Figure 1). Detailed mortuary analyses have already been

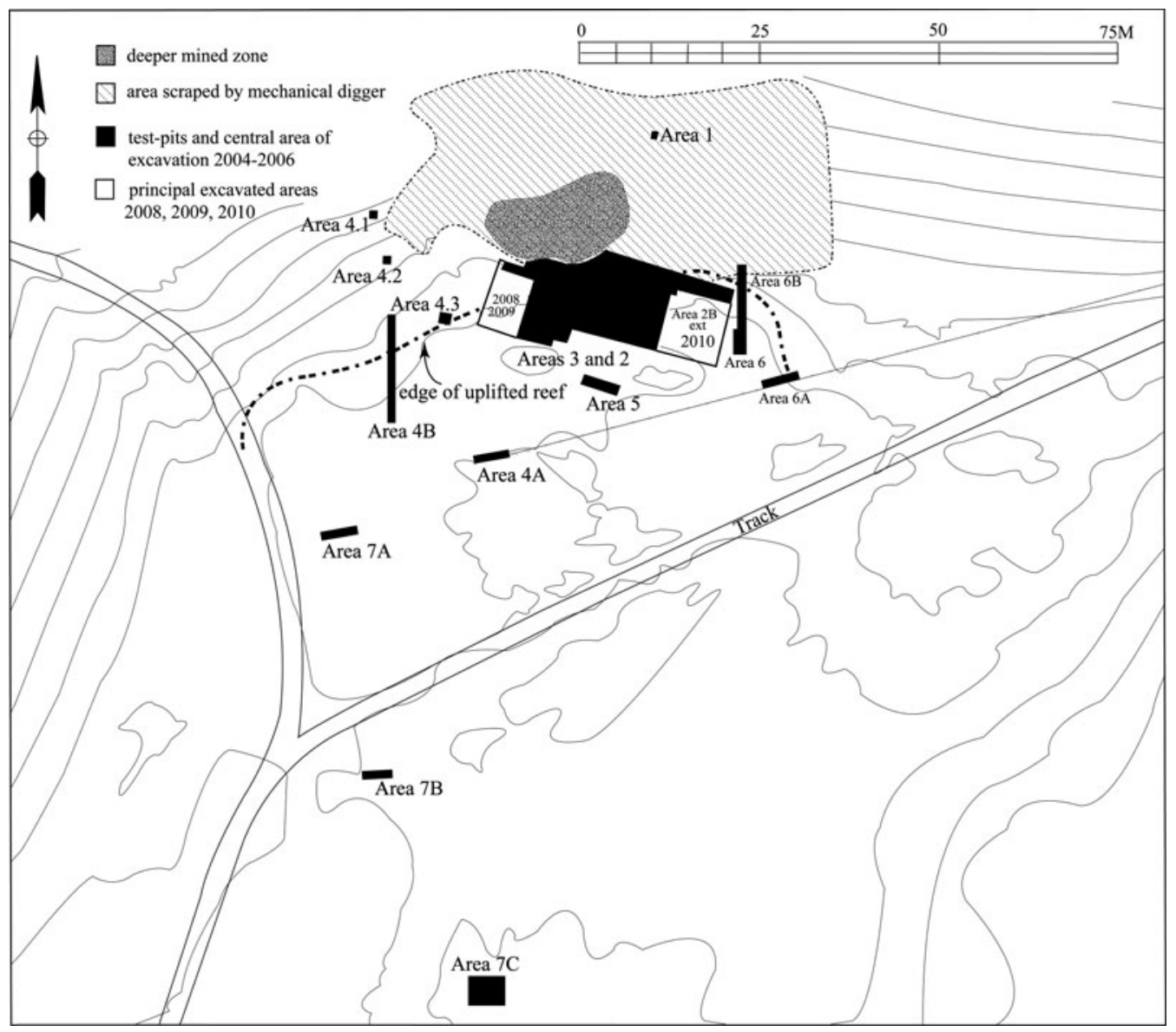

Figure 1. Map of the site of Teouma (central Vanuatu). 
Table 1. Radiocarbon dates from Teouma (central Vanuatu) Area $7 \mathrm{C}$ and backhoe Trench 3.

\begin{tabular}{lll}
\hline Burial N & Lab N ${ }^{\circ}{ }^{14}$ C age & $\begin{array}{c}\text { Calibrated date (68.2\% } \\
\text { probability range) }\end{array}$ \\
\hline Area 7C B1 & ${ }^{*}$ Wk-24480, 2423 $\pm 30 \mathrm{BP}$ & $2460-2352 \mathrm{BP}$ \\
Area 7C B2A & $*$ Wk-24481, 2455 $\pm 30 \mathrm{BP}$ & $2653-2365 \mathrm{BP}$ \\
Area 7C B2B & $*$ Wk-24482, 2465 $\pm 30 \mathrm{BP}$ & $2682-2364 \mathrm{BP}$ \\
Area 7C B3 & $*$ Wk-24483, 2423 $\pm 30 \mathrm{BP}$ & $2463-2355 \mathrm{BP}$ \\
Area 7C B4 & $*$ Wk-24484, 2452 $\pm 30 \mathrm{BP}$ & $2655-2645 \mathrm{BP}$ \\
Trench 3 B1 & Wk-30871, 2501 $\pm 27 \mathrm{BP}$ & $2696-2460 \mathrm{BP}$ \\
Trench 3 B2 & Wk-30872, 2422 $\pm 27 \mathrm{BP}$ & $2456-2348 \mathrm{BP}$ \\
\hline
\end{tabular}

\footnotetext{
*In Valentin et al. (2011).

Calibrated radiocarbon dates are at two standard deviations using OxCal 4.1 (Bronk Ramsey 2009), with a delta-R of $40 \pm 44$ for Vanuatu marine shell samples as calculated by Fiona Petchey (University of Waikato, Radiocarbon Dating Laboratory). The bone dates from Teouma Area $7 \mathrm{C}$ were calibrated by Fiona Petchey using mixed marine and terrestrial curves based on measured isotope data. We have opted to use INTCAL 09 for all terrestrial calibrations, and have not incorporated a Southern Hemisphere offset given the position of the thermal equator at the Inter Tropical Convergence Zone (ITC Z) as the boundary between the atmospheres of the Southern and Northern Hemispheres (see Petchey et al. 2011:34).
}

published for 29 of the 71 inhumations (Valentin et al. 2010a) and one cremation (Scott et al. 2010) from Areas 2 and 3 of the Lapita cemetery. Valentin et al. (2009) briefly summarized mortuary data recorded on 44 Lapita burials there while the five Erueti burials from Area $7 \mathrm{C}$ were briefly presented in Valentin et al. (2011). Published isotopic dietary data (at the time of article acceptance) only concern Lapita individuals from Areas 2 and 3 , including 33 adults recovered in primary contexts and seven infants (Kinaston et al 2009; Valentin et al. 2010b).

Building on these previous analyses, this study for the first time compares a sample of 50 adult burials from the Teouma Lapita and immediately Post-Lapita periods using both mortuary and isotopic dietary data. Forty-three were Lapita inhumations excavated during the first three field seasons (2004-2006) in Area 2 and 3 and seven were Erueti period inhumations recovered during the 2008 and 2010 excavations in Area 7C and Trench 3. Confirming their attribution to the Lapita period, burials in Areas 2 and 3 were placed at the base of the stratigraphy, associated with Lapita pots and artifacts radiocarbon dated to c. $2900 \mathrm{BP}$ (Bedford et al. 2006, 2009). In the absence of distinc- tive material culture associations, burials in Area $7 \mathrm{C}$ and Trench 3 were attributed to the Erueti period based on radiocarbon dating (Table 1).

\section{METHODS}

Mortuary Data Collection and "Anthropologie de Terrain"

Mortuary data collection, aiming to define the type of body treatment that was undertaken has focused on two aspects. The first deals with the anatomical composition of each burial to identify the skeletal elements present in situ, thereby identifying and interpreting any loss in elements. The second concerns the spatial distribution of the skeletal elements within the grave, analyzed following the methodology of "Anthropologie de Terrain" (Duday 1990, 2009; Duday et al. 1990; and see Ortiz et al. 2013 for a review). In short, "Anthropologie de terrain" attempts to reconstruct the initial conditions of burial (initial body position, body manipulation, presence of body container), taking account of subsequent taphonomic distortions. It focuses on data collected in 
the field including: visible aspect of the bone in plan view; state of articulation of each joint (fully articulated, partially articulated, disarticulated); relocation of bone or body segment within the grave; and delimiting and restraining effects on the skeleton.

\section{Stable Isotope Analysis and Modeling Diet}

Stable isotope ratios are routinely used in the Pacific area to reconstruct past dietary behaviors and subsistence strategies (i.e., Ambrose et al. 1997; Valentin et al. 2010b; and see Kinaston and Buckley 2013 for a review). This is because carbon isotope ratios can discriminate between the consumption of marine and terrestrial products, and nitrogen isotope ratios allow assessment of the amount of animal, including marine, protein in the diet (Katzenberg and Saunders 2008; Schoeninger 2010). In addition, models of dietary reconstruction (Phillips and Koch 2002) allow a simplified representation of the diet for an individual or a population by integrating the isotope values of several foods potentially consumed. Based on such an approach, two modeling sets were applied for the first time both to Teouma Lapita and Erueti individuals to characterize human dietary patterns and quantify the relative contributions of different dietary sources. The first set of modeling was run with the Iso-Conc mixing model (Phillips and Koch 2002) using exclusively isotopic data from currently published prehistoric Teouma food resources, so as to be closest to the environmental conditions likely to have been experienced by the humans recovered from the site (individual data from the literature [Table 2] while another set of data has just been published [Kinaston et al. 2014]). These resources divide into three dietary poles corresponding to flesh from herbivores (land-turtles and fruit bats), omnivores (pigs, rat, and chicken), and marine (reef-fish) species. The second set of modeling was run with the IsoSource mixing model (Phillips and Gregg 2003) which allows calculations of proportions of more than three dietary sources and therefore addition of a second marine pole representing offshore fish, absent in the Teouma isotopic record. Carbon $(n=23)$ and nitrogen $(n=14)$ iso- topic data measured on offshore fish of the Pacific area and published by Ambrose et al. (1997) and Leach et al. (1996) were used to this end. Carbon and nitrogen isotope ratios $\left(\delta^{13} \mathrm{C}\right.$ and $\left.\delta^{15} \mathrm{~N}\right)$ were measured in bone collagen of 26 of the 43 Lapita burials (individual data in Valentin et al. 2010b) and 6 of the 7 Erueti burials. Erueti burial bone collagen was extracted using a protocol described elsewhere (Herrscher and Le BrasGoude 2010). Carbon and nitrogen isotope analyses were carried out by Elemental Analysis and Isotope Ratio Mass Spectrometry (Europea Scientific EA and Europa Scientific 20-20 IRMS). Isotopic measurement reproducibility is inferior to $0.1 \%$ for both carbon and nitrogen. Six collagen extractions were considered well enough preserved to interpret their isotope data in a dietary perspective despite low percentages of carbon and nitrogen contents (Ambrose and Norr 1993; DeNiro 1985). The seventh (from Trench 3B1) exhibited a yield of collagen extraction under $10 \mathrm{mg} . \mathrm{g}^{-1}$ and was discarded (Table 3) (van Klinken 1999).

\section{RESULTS AND INTERPRETATION}

Mortuary Evidence

The mortuary evidence presents a clear contrast between Lapita and Erueti burials in relation to five components defining treatment of the deceased: body position, bone manipulation, bone collection, ornaments and grave goods. Comparisons between the Lapita and Erueti period burials primarily highlight differences in body position. Original body position was reconstructed at least partially for 28 Lapita and 5 Erueti burials. The Lapita bodies were laid on the back (22 burials) and face down (6 burials) with a high level of variation in lower limb positions (Table 4 and Figure 2). Hips and knees were generally flexed (17 burials), with various degrees of flexion and in various planes (Table 4). Hips and knees were fully extended with lower limbs parallel in only 9 burials of this sample. In contrast, the Erueti sample displays a limited range of variation of body positions, including on the back with the lower limbs extended ( 1 burial) and on the side with the lower limbs semi-flexed ( 4 


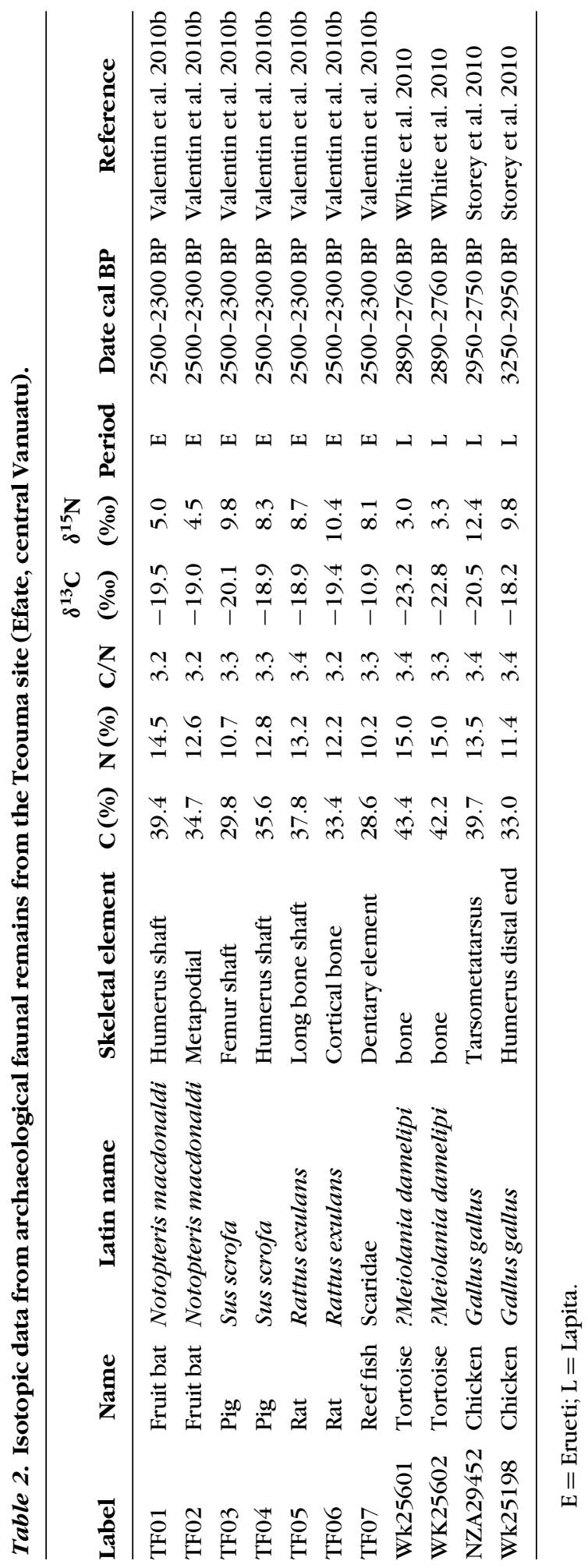


Table 3. Isotopic data of Erueti (c. $2400 \mathrm{BP}$ ) period human remains from the Teouma site (Efate, central Vanuatu).

\begin{tabular}{|c|c|c|c|c|c|c|c|c|}
\hline Burial N $^{\circ}$ & Location & Skeletal element & $\begin{array}{c}\text { Yield } \\
(\mathrm{mg} / \mathrm{g})\end{array}$ & C $(\%)$ & $\mathbf{N}(\%)$ & $\mathbf{C} / \mathbf{N}$ & $\begin{array}{l}\delta^{13} \mathrm{C} \\
(\% 0)\end{array}$ & $\begin{array}{l}\delta^{15} \mathbf{N} \\
(\%)\end{array}$ \\
\hline Burial 1 & Area 7C & Long bone shaft & 30.3 & 23.2 & 8.1 & 3.3 & -19.7 & 9.2 \\
\hline Burial 2A & Area 7C & Parietal & 21.2 & 28.6 & 10.0 & 3.3 & -19.7 & 9.1 \\
\hline Burial 2B & Area $7 \mathrm{C}$ & Long bone shaft & 14.1 & 26.6 & 9.4 & 3.3 & -19.7 & 8.2 \\
\hline Burial 3 & Area 7C & Maxilla & 39.3 & 34.4 & 12.1 & 3.3 & -19.7 & 8.3 \\
\hline Burial 4 & Area $7 \mathrm{C}$ & Vertebra & 21.1 & 27.1 & 9.5 & 3.3 & -19.2 & 9.3 \\
\hline Trench 3-B1 & Trench3 & Long bone shaft & 6.0 & - & - & - & - & - \\
\hline Trench 3-B2 & Trench3 & Long bone shaft & 16.2 & 29.6 & 10.5 & 3.3 & -19.0 & 8.2 \\
\hline
\end{tabular}

burials) (Figure 3). Although in articulation, the Lapita skeletons in primary contexts (34 burials minus 2 altered by further activities at the site) are incomplete to varying degrees, with a similar pattern of missing elements (Figure $2 \mathrm{~A}, \mathrm{~B}, \mathrm{C}$ ). Skulls in the correct anatomical position were systematically absent, forearm bones were frequently lacking, along with clavicles, scapulae, sterna, humeri, and ribs, while isolated teeth, hyoid bones and hand bones were uncovered in situ in most cases. This repetitive pattern is interpreted as reflecting a practice of postdecomposition bone removal and thus of secondary burial as defined by Hertz in 1907 (Valentin et al. 2009, 2010a), while taphonomic processes were responsible for localized bone loss and fragmentation (Figure 2).

Table 4. Lower limb positions in the studied Teouma Lapita burials.

\begin{tabular}{llc}
\hline Lower limb position & \multicolumn{1}{c}{ Burials } & $\begin{array}{c}\text { Number of } \\
\text { burials }\end{array}$ \\
\hline $\begin{array}{l}\text { Hips and knees extended, lower limb parallel } \\
\text { Hips extended and knees reversed-flexed, lower } \\
\text { legs parallel or crossed }\end{array}$ & B 5, 12, 15, 16, 34, 36, 38, 40, 47 & 9 \\
$\begin{array}{l}\text { Hips extended with the knees flexed, lower legs } \\
\text { against thighs }\end{array}$ & B 9, 25, 37 18, 32, 33 (see Figure 2C) & 5 \\
$\begin{array}{l}\text { Hips flexed and knees semi-flexed in the sagittal } \\
\text { plane }\end{array}$ & B 8, 10, 14, 31, 44 (see Figure 2A) & 3 \\
$\begin{array}{l}\text { Hips flexed with lower limbs folded over the } \\
\text { torso, extended and crossed }\end{array}$ & B 48 (see Figure 2B) & 5 \\
$\begin{array}{l}\text { Hips flexed with lower limbs extended, folded on } \\
\text { the side }\end{array}$ & B 49 & 1 \\
$\begin{array}{l}\text { Hips flexed with knees highly flexed against the } \\
\text { chest (B19) }\end{array}$ & B 19 \\
$\begin{array}{l}\text { Hips in abduction, knees flexed, and lower legs } \\
\text { crossed }\end{array}$ & B 7 & 1 \\
$\begin{array}{l}\text { Hips extended and knees unknown } \\
\text { Hips and knee unknown }\end{array}$ & B 2 & 1 \\
\hline
\end{tabular}



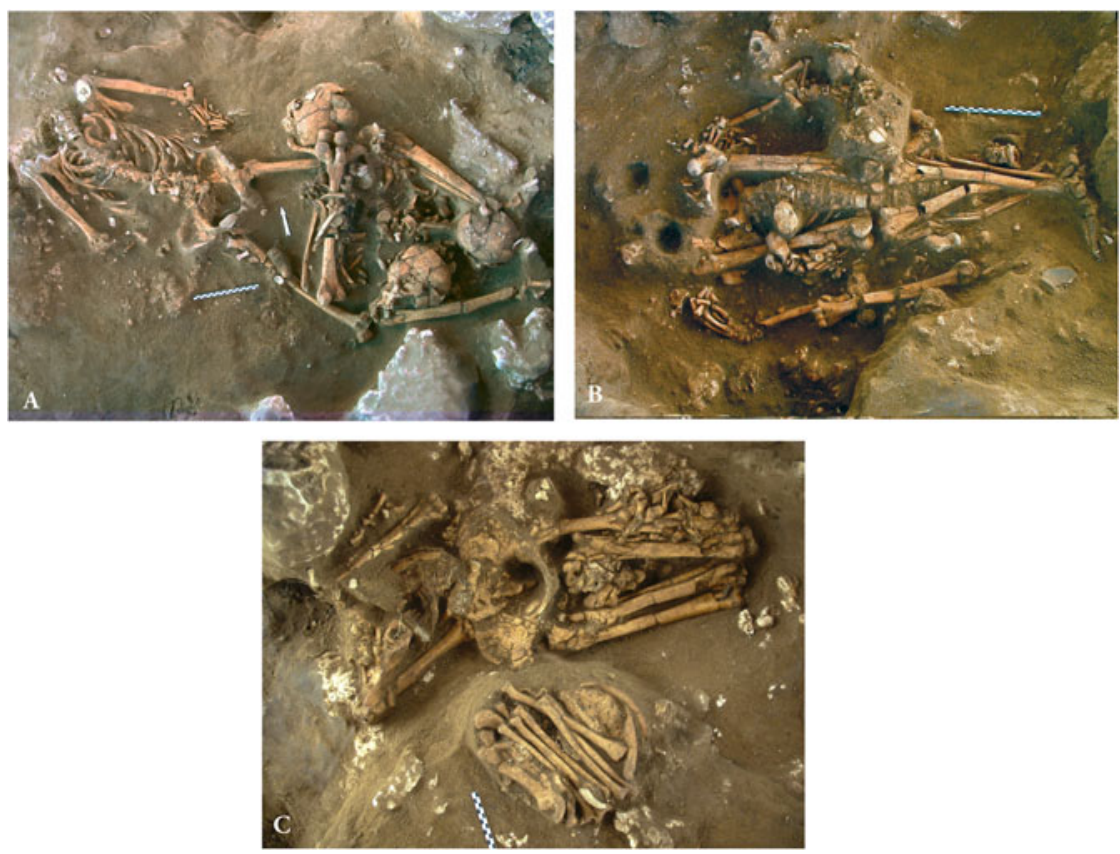

Figure 2. Examples of burial contexts recovered at Teouma Lapita cemetery (Efate, central Vanuatu). A: Burials B44 and B3O, B3O is a bone collection including up to five individuals that has been placed on the knees of B44; B: Burials B48 and B46, B48 is an incomplete inbumation, $B 46$ is an infant inhumation placed later above B48's right elbow; C: Burials B33 and B39, B39 comprises a bundle of forearm bones and B33 is an incomplete inhumation; Originally, B44 was laid on the back, bips extended and knees flexed in the sagittal plane, B48 was on the back with the hips flexed and the lower limbs extended and crossed, folded over the torso, B33 was on the back, hips extended and knees reversed-flexed, lower legs over thighs. $B 44,48$, and 33 are incomplete inhumations of which several bones including skull and forearm bones (B44 and 33) were removed after body decomposition. Note the in situ bone fragmentation in all burials.

At the opposite end of the spectrum, and despite poorer relative preservation due to the shallow depth of interment, the Erueti burials all comprised a virtually complete individual, with each part of the skeleton represented. This reflects the practice of inhumation as a simpler and more definitive form of disposal.

Moreover, Lapita bodies were manipulated in situ during decomposition and segments of corpse and bones were re-arranged in the grave ( 4 burials). In addition, nine structured human-bone collections of various forms (Figure 2, A and C), sometimes enclosed in dentate-stamped decorated pottery vessels, were deposited beside or with some of the incomplete skeletons. Similarly a range of burial goods such as dentatestamped pottery vessels, sometimes of exotic provenience and of various shapes and sizes, unworked bivalve shells, Conus sp. shell rings, and other ornaments comprising shell beads and bracelets were associated with some of the incomplete Lapita inhumations (Bedford et al. 2009, 2010). Contrasting with this material wealth, the Erueti burial areas are characterized by a lack of any associated bone depositions. They also showed no sign of body and bone manipulation, nor bone collections, ornaments, or other nonperishable grave goods (Figure 3 ).

Finally, the Teouma population associated with the Lapita phase demonstrates a high level of interaction with their dead 


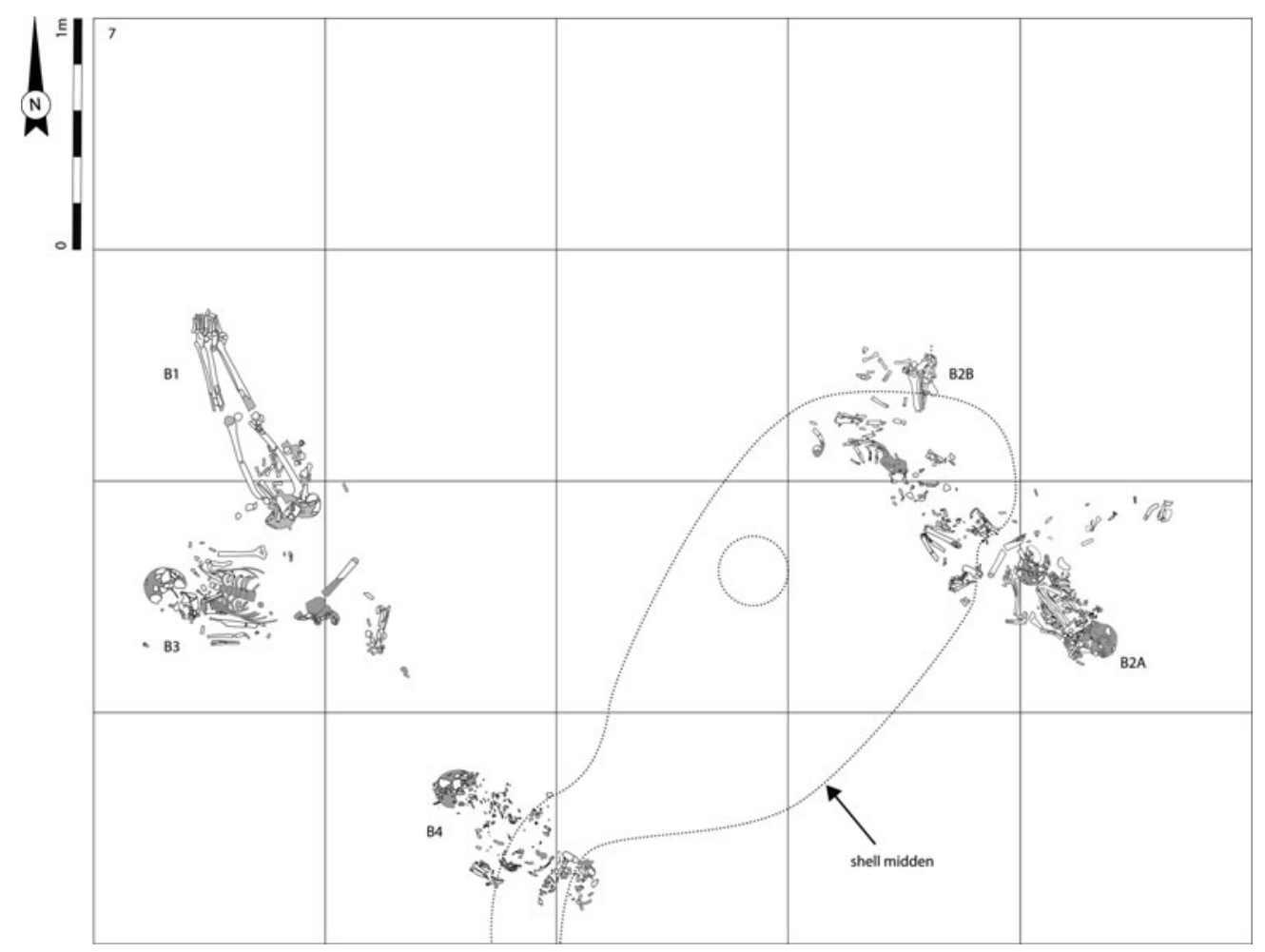

Figure 3. Erueti burial cluster recovered at Teouma site (area 7C) (Efate, central Vanuatu).

and their bones and had at the same time a wide sphere of interaction, indicated by long-distance exchanges (Dickinson et al. 2013; Reepmeyer et al. 2011). In contrast, the Teouma population associated with the Erueti phase maintained an apparently lower level of interaction with the dead and presented a reduced sphere of interaction, significant long-distance relations having ceased by the end of the Lapita period (Reepmeyer et al. 2011). While the general ethnographic record suggests that mobile groups are less likely to practice secondary burial (Schroeder 2001:88), this may not apply to early colonizing groups in the Pacific arriving in pristine environments. The multistage burial practice at Teouma may pertain to a general strategy, which aimed at facilitating the survival of Lapita groups scattered across a vast and thinly populated region of the southwest Pacific (Bedford et al. 2011; Clark 2007). Further indications of such a shared funerary system can be seen in the association of exotic vessels with the Teouma burials and at the site of Lapita (Koné) in New Caledonia where human bone and body manipulation is in evidence (Valentin et al. 2005). The burial method used during the Erueti phase, expressed by a single archaeologically visible event, reflects a radically different attitude of the living towards the dead and death, and possibly towards social relationships (Valentin et al. 2011).

\section{Dietary Evidence}

Considered together, animal carbon and nitrogen available data range from -23.2 to $-10.9 \%$ and 3.0 to $10.4 \%$ respectively, with an expected relative position of the different species (Table 2; Figure 4). The Arapus/Erueti period rats and pigs present the most comparable isotopic results for both carbon and nitrogen, between -18.2 and 


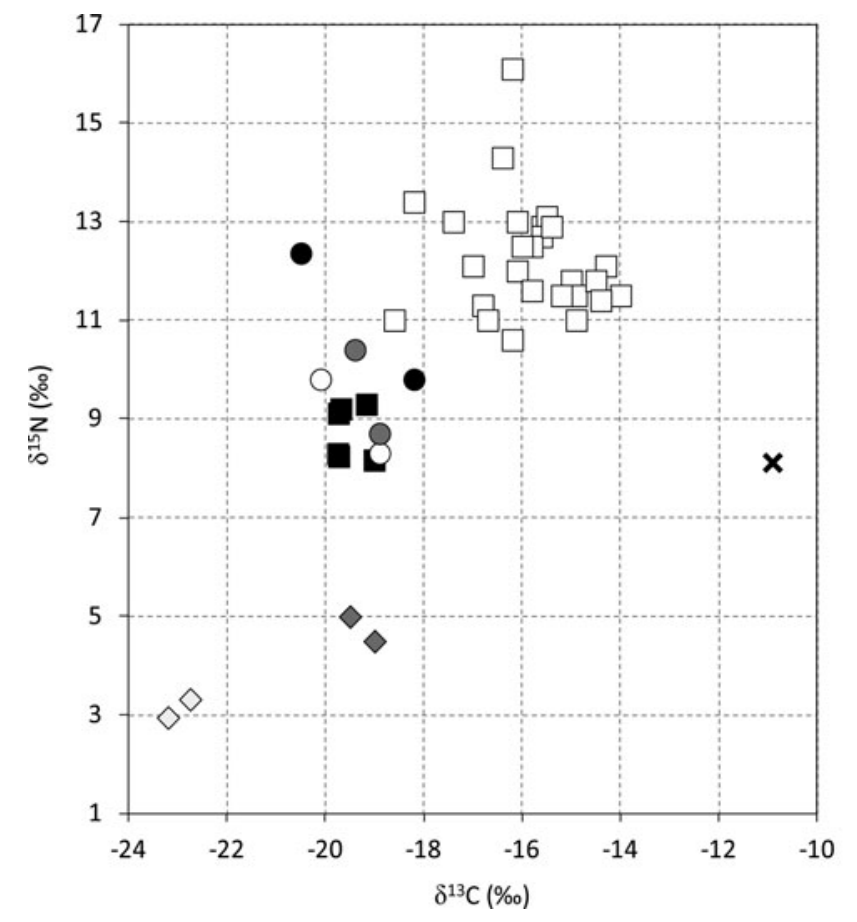

Humans

$\square$ Lapita ( $n=26$, Valentin et al 2010)

Erueti $(n=6)$

Animals

$\diamond$ Tortoise ( $n=2$, White et al 2010)

$\diamond$ Bat ( $n=2$, Valentin et al 2010)

O Pig ( $n=2$, Valentin et al 2010)

- Rat ( $n=2$, Valentin et al 2010)

- Chicken ( $n=2$, Storey et al 2010)

XScaridea fish ( $n=1$, Valentin et al 2010)

Figure 4. Carbon and nitrogen stable isotope values of bone collagen from Teouma (Efate, central Vanuatu) buman and animal bone data.

$-20.1 \%$ and 8.3 and $12.4 \%$ respectively, indicating consumption of isotopically similar food items. Land-turtles exhibit the lowest carbon and nitrogen values $(-23.2$ and $-22.8 \%$; 3.0 and 3.3\%0). These values are close to values measured on $\mathrm{C}_{3}$ plants from Pacific Islands (Ambrose et al. 1997; Keegan and DeNiro 1988), confirming the vegetarian diet of these specimens. Comparison between isotopic data for land-turtles and bats reveals higher carbon and nitrogen values among the bats $(-19.5$ and $-19.0 \% ; 4.5$ and $5.0 \%$ ), suggesting that bats may have consumed a wider range of food items. Despite the small sample size, it is interesting to note that the chicken specimens from the Lapita period present a higher mean value for nitrogen than the Arapus/Erueti omnivore specimens $(11.1 \% ; n=2)$ versus $9.3 \%(n=4)$. As proposed by Storey et al. (2010), such a result could indicate higher consumption of animal protein. However, particular environmental conditions during the earliest period could also be suggested. Specific environments such as dry and hot zones are known to induce an enrichment in nitrogen values across the food web, through plants up to the end-members (Ambrose 1991; Dupras et al. 2001, Schwarcz et al. 1999; Sealy et al. 1987). Aridity could have been one of the factors that elevated the nitrogen values of the local Lapita food web, based on a palaeoenvironmental study arguing that drier environmental conditions were experienced in the Teouma region c. 3500-3250 cal BP, slowly ameliorating by $2500 \mathrm{cal} \mathrm{BP}$ (Wirrmann et al . 2011).

The Erueti individuals exhibit carbon and nitrogen isotope values ranging respectively from -19.7 to $-19 \%$ and 8.2 to $9.3 \%$ whereas the Lapita individuals show higher values respectively from -18.6 to $-14 \%$ and 10.6 to $16.1 \%$ o (Valentin et al. $2010 \mathrm{~b}$; Figure 4; Tables 3 and 5). A U-Mann-Whitney test indicates significant differences for both carbon and nitrogen values. The significant 


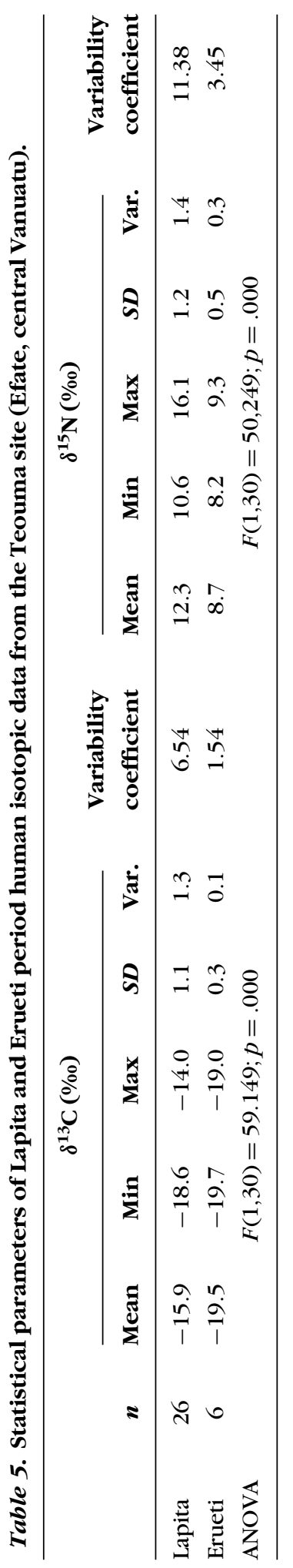


isotopic impoverishment in 13-carbon and 15-nitrogen indicates a modification in dietary practices through time, marked by change in both the nature of the protein and the quantity of animal protein consumed. In addition, as highlighted by calculation of the coefficient of variability, the variability within each group is different (Table 5). Dispersion around the mean value of both carbon and nitrogen isotopes are clearly higher in the Lapita group than in the Erueti group which forms a narrow cluster (Figure 4). These results indicate heterogeneity in the individual Lapita dietary intake and a higher level of homogeneity among Erueti individuals.

In terms of quantification, IsoConc simulations based on three dietary poles indicate that the Lapita diet was richer and more diversified than the Erueti diet. The former balanced Scaridae fish-flesh (32.4\%), herbivore flesh and/or $\mathrm{C}_{3}$ vegetal items (17.0\%), and omnivore flesh (50.6\%), while the latter consisted mainly of herbivore flesh and/or $\mathrm{C}_{3}$ plants (85.4\%) (Figure 5). With the addition of offshore fish-flesh as a fourth dietary pole, IsoSource simulations confirm the dietary shift between the Lapita and Erueti groups (Figure 6). Again, whereas the Lapita diet combines almost equally the four poles (from $16.2 \%$ of reef fish-flesh to $33.5 \%$ of herbivore flesh), the Erueti diet is unevenly distributed, involving primarily herbivore flesh and/or vegetal items (87.6\%).

The decrease in high trophic level food items such as animal resources in the diet could echo the decline in wild native prey availability through extinction observed in the Vanuatu faunal assemblages (Bedford 2006). Alternatively, this dietary pattern might reflect the Erueti social structure, with a group of people sustained by a uniform diet focused on a limited number of terrestrial items and generally excluding meat of domesticated animals. Remains of domesticated animals are regularly found throughout the central Vanuatu first millennium BC sequence (Bedford 2006) suggesting that, despite their presence, the Teouma population associated with the Erueti culture were not usually dependent on this potential dietary resource. Through time, one may observe a

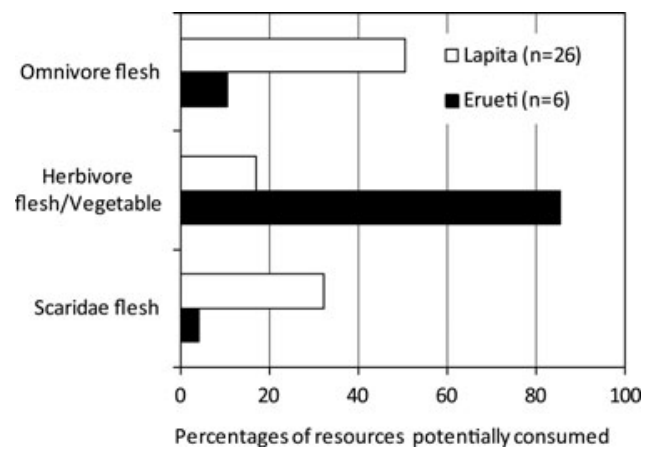

Figure 5. Dietary isotopic simulations for the two Teouma buman groups with IsoConc software (C) Microsoft Excel software, bttp://www.epa.gov/wed/ pages/models.htm, 3 sources/2 isotopes; Pbillips and Koch 2002).

trend in dietary choices operated by people focusing on vegetal items without excluding the input of herbivore flesh as flesh of vegetarian bats. This increasing interest in vegetal foods could be seen as following on from favorable environmental conditions or improved horticultural techniques.

\section{DISCUSSION}

Despite the small size of the Erueti sample and if we consider that both samples are representative of their respective cultures, the analysis presented in this paper highlights major diachronic changes in two significant aspects of human behavior, illustrating an alteration of investment in funerary rituals at the same time as the agricultural economy becomes fully established. The first concerns funerary practices, with the abandonment of a lengthy and complicated protocol (involving bone exhumation and reburial) displaying diversity among adults for a simpler and definitive process of primary inhumation showing uniformity among adults. The second change is in dietary practices, with the abandonment of a broad-based diet comprising marine resources (summed IsoSource percentages: $36.9 \%$ Lapita versus $4.8 \%$ Erueti) showing heterogeneity among 
Humans

$\square$ Lapita $(n=26)$

Erueti $(n=6)$
Resources potentially consumed

Herbivore flesh $(n=4)$

Omnivore flesh $(n=6)$

$\diamond$ Scaridae fish

$\triangle$ Offshore fish
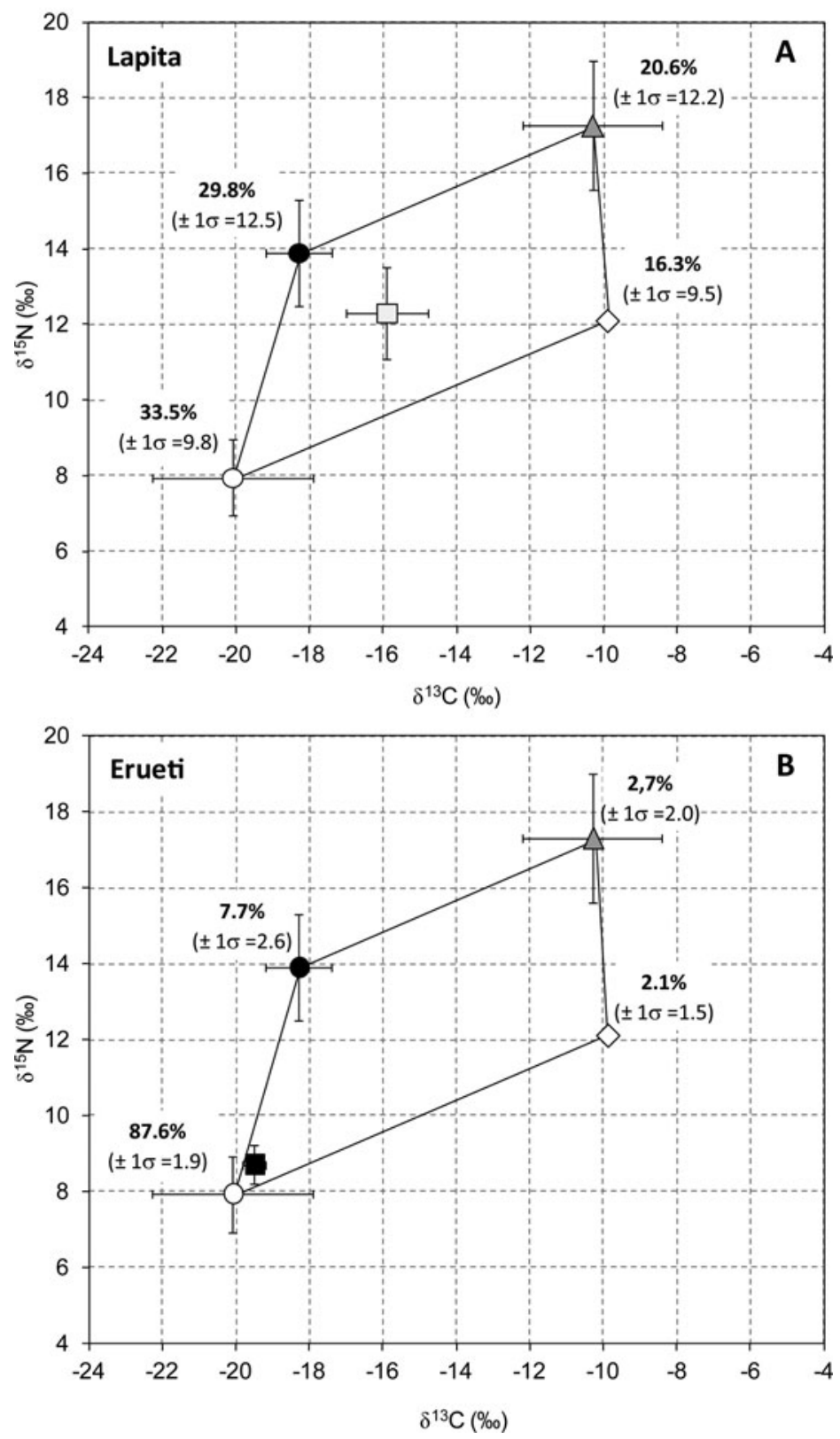

Figure 6. Dietary isotopic simulations with IsoSource software for the Lapita (A) and Erueti (B) groups (C1.3.1 Visual Basic, bttp://epa.goc/wed/pages/models.btm, Phillips and Gregg 2003). Offshore fish resource isotopic data from Ambrose et al. 1997 and Leach et al. 1996. 
individuals for the quasi-exclusive use of terrestrial resources mainly composed of low trophic level foods by all the individuals (63.3\% Lapita versus $95.3 \%$ Erueti). The two behavioral modifications identified here constitute additions to changes over time from the Lapita period to the Erueti period, already recorded at Teouma (Bedford 2009; Bedford et al. 2010; Reepmeyer et al. 2011). They include changes in mobility patterns, land use, artifact manufacture and provenience. Changes in ceramic production are interpreted as the result of a gradual internal process, a demonstrated continuity in vessel form and decoration supporting the view that there was a local development of the ceramic technology (Bedford 2009).

The changes in funerary and dietary perception and practice can be seen as further indications of adaptation to changing local conditions and constraints. As for Hawai'i (Kirch 1985, 2007, 2010), an archipelago characterized by major diachronic changes in settlement pattern, land use, agricultural technology, and sociopolitical organization (some centuries after initial colonization and Tahitian contact about AD 1300), a demographic transition concomitant with political change and cultural innovation is a plausible explanation for the alteration in the economic, symbolic, and religious components of the social system observed at Teouma.

Environmental and climatic conditions could also have influenced the development of horticulture in central Vanuatu. Haberle and Chepstow Lusty (2000:357) noted that "increased drought stress associated with ENSO [El Niño-Southern Oscillation] events are considered to have had a significant influence on vegetation dynamics in the Pacific region over the last five to three millennia," although effects can vary greatly over relatively short geographical distances (Allen 2006; Morrison and Addison 2008). The possibility of a negative impact of drier conditions on the Teouma food web during the Lapita period suggested by the isotopic data at hand, while needing to be further assessed using a larger isotopic faunal dataset, is supported by local palaeoenvironmental data (Wirrmann et al. 2011). The difficult local growing conditions, which appear to have improved by $2500 \mathrm{BP}$ (Wirrmann et al. 2011), might have delayed an early horticultural expansion and consequently an early regular integration of vegetable foods in the diet.

Early secondary contacts and migration could also have complicated the Teouma picture (see Green 1963; Spriggs 1997). Indeed, it should not be entirely ruled out that cultigens and the vegetarian trend of Erueti dietary habits reflected in our isotopic data were introduced later in time in Vanuatu, as has been proposed for other parts of Remote Oceania (Clark and Anderson 2009). There is direct evidence for several cultivated crops in Vanuatu at least for Late Lapita and Erueti periods. Non-Colocasia aroid starch residues, Dioscorea sp. starch grains and banana (Musa sp.) phytoliths have been identified in Late Lapita sediments from northern Vanuatu while banana (Musa sp.) phytoliths are present in Early Erueti period sediments from Epi Island in central Vanuatu (Horrocks and Bedford 2005, 2010; Horrocks et al. 2009). There is also evidence that the change in funerary practices began to occur at the end of the Lapita period (Bedford et al. 2011; Valentin et al. 2011). Simple primary inhumation of adults has been identified in Late Lapita burials from Vao Island in north Vanuatu (Bedford et al. 2011) as well as in Late Lapita and immediately Post-Lapita burials from Fiji (Nunn 2007; Pietrusewsky et al. 1997) and New Caledonia (Pietrusewsky et al. 1998; Valentin 2003). Furthermore, the possibility of long-distance contacts with northern Melanesia at the very end of the Lapita period is now supported by the discovery of a piece of Mopir obsidian at Teouma (Reepmeyer et al. 2011). The Mopir obsidian sources were covered by volcanic deposits from the Witori eruption of c. $3350 \mathrm{cal} \mathrm{BP}$, and seem only to have become available again in small quantities in Late Lapita times (Summerhayes 2009). It is thus a possibility that new mortuary and subsistence practices were brought in or influenced by newcomers, most likely during the Late Lapita phase as regional interaction largely ended at the end of Lapita. Levels of contact and/or influence were likely to have varied greatly from one region to another during Late Lapita times. Such contact-induced 
changes could have contributed to the high levels of cultural diversity suggested to have emerged at the end of the Lapita period in Island Melanesia (Bedford and Clark 2001; Spriggs 2004).

\section{CONCLUSION}

Analysis of the burials from the site of Teouma (central Vanuatu) demonstrates a clear shift in both usually conservative funerary and dietary habits over time and a major change affecting the economic component of the social system and its associated symbolic and religious structures. The Lapita adults received a complicated, multi-stage, mortuary treatment with a high level of interindividual diversity. These same Lapita individuals appear also to have benefited from a diet including a wide range of food items, almost evenly consumed, but with a high range of variation within the population. In contrast, Erueti individuals received a simplified and less diversified funerary treatment. They also appear to have been sustained by a diet of more restricted breadth comprising a limited range of food items of low trophic level such as vegetal resources and herbivore flesh, coupled with dietary homogeneity among individuals.

Adaptive responses to local conditions and/or constraints appear at this stage to be a convincing hypothesis to explain a lack of culturally stable transmission in mortuary and dietary practices, as well as in some other cultural practices, from the Lapita to Erueti periods; but the intertwined actions of other factors remain to be further explored. There may have been climatic conditions that affected the environmental potential for horticultural development in the islands and/or a later introduction to the region of particular mortuary and subsistence practices brought or influenced by newcomers. There could also have been broader initial behavioral diversity than usually considered among Lapita settlers and a rearrangement of cultural practices over time. The significant challenge is in teasing apart these various possibilities and this will require more focused analysis of a range of human biological features and an increased sample of archaeological materials of all types across space and time in the Vanuatu archipelago and the wider region.

\section{ACKNOWLEDGEMENTS}

The Teouma Archaeological Project is a joint initiative of the Vanuatu National Museum and The Australian National University (ANU), directed by Professor Matthew Spriggs and Dr. Stuart Bedford of the ANU and Mr. Ralph Regenvanu and Mr. Marcellin Abong, Directors of the Vanuatu Cultural Centre. Funding for the project is acknowledged in full in earlier publications. Thanks to Guy André (CNRS UMR 7269, LAMPEA) for technical belp in collagen preparation. Elemental and isotopic measurements were performed at IsoAnalytical Limited (Crewe, UK). Thanks to Fiona Petchey (Waikato Radiocarbon Dating Lab) for ${ }^{14} \mathrm{C}$ date calibrations, to Maurice Hardy (CNRS UMR 7041 ArScAn) and Florence Alliése for assistance in the production of the illustrations, and Prof. Ian Lilley (University of Queensland, Australia) for comments on an earlier version of the manuscript. Thanks also to the anonymous reviewers and editors for their belpful comments. The support of the leasebolder of Teouma, Mr. Robert Monvoisin, and family is acknowledged, as is the support and assistance of the traditional landowners and population of Eratap Village.

\section{REFERENCES}

Allen, M. 2006. New ideas about late Holocene climate variability in the central Pacific. Current Antbropology 47(3):521-535.

Ambrose, S. H. 1991. Effects of diet, climate and physiology on nitrogen isotope abundances in terrestrial foodwebs. Journal of Archaeological Science 18:293-317.

Ambrose, S. H., B. M. Butler, D. B. Hanson, R. L. Hunter-Anderson, and H. W. Krueger. 1997. Stable isotopic analysis of human diet in the Marianas archipelago, Western Pacific. American 
Journal of Physical Anthropology 104:343361.

Ambrose, S. H. and L. Norr 1993. Experimental evidence for the relationship of the carbon isotope ratios of whole diet and dietary protein to those of bone collagen and carbonate. In Prebistoric Human Bone Archaeology at the Molecular Level (J. B. Lambert and G. Grupe, eds.):1-37. Berlin: Springer-Verlag.

Anderson, A., J. Chappell, M. Gagan, and R. Grove. 2006. Prehistoric maritime migration in the $\mathrm{Pa}-$ cific Islands: An hypothesis of ENSO forcing. The Holocene 16(1):1-6.

Bedford, S. 2006. Pieces of the Vanuatu Puzzle: Archaeology of the North, South and Centre. Canberra: Terra Australis 23, The Australian National University, Pandanus Press.

Bedford, S. 2009. Les traditions potières Erueti et Mangaasi du Vanuatu central: Réévaluation et comparaison quarante ans après leur identification initiale. Journal de la Société des Océanistes 128:25-38.

Bedford, S., H. Buckley, F. Valentin, N. Tayles, and F. Longga. 2011. Lapita burials, a new Lapita cemetery and post-Lapita burials from Malakula, northern Vanuatu, Southwest Pacific. Journal of Pacific Archaeology 2(2):26-48.

Bedford, S. and G. Clark. 2001. The rise and rise of the incised and applied relief tradition: A review and reassessment. In The Archaeology of Lapita Dispersal in Oceania (G. R. Clark, A. J. Anderson, and T. Vunidilo, eds.):61-74. Canberra: Terra Australis 17, The Australian National University, Pandanus Books.

Bedford, S. and M. Spriggs. 2007. Birds on the rim: A unique Lapita carinated vessel in its wider context. Archaeology in Oceania 42:12-21.

Bedford, S., M. Spriggs, H. Buckley, F. Valentin, and R. Regenvanu. 2009. The Teouma Lapita site, south Efate, Vanuatu: A summary of three field seasons (2004-2006). In Lapita: Ancestors and Descendants (P. Sheppard, T. Thomas, and G. Summerhayes, eds.):215-234. Auckland: New Zealand Archaeological Association Monograph 28.

Bedford, S., M. Spriggs, H. Buckley, F. Valentin, R. Regenvanu, and M. Abong. 2010. Un cimetière de premier peuplement: le site de Teouma, sud Efate, Vanuatu/A cemetery of first settlement: Teouma, south Efate, Vanuatu. In Lapita: Ancêtres Océaniens/Oceanic Ancestors (C. Sand and S. Bedford, eds):140-161. Paris: Somogy Editions d'Art/Musée du Quai Branly.

Bedford, S., M. Spriggs, and R. Regenvanu. 2006. The Teouma Lapita site and the early human settlement on the Pacific islands. Antiquity 80(310):812-828.
Bronk Ramsey, C. 2009. Bayesian analysis of radiocarbon dates. Radiocarbon 51(1):337-360.

Clark, G. 2007. Specialisation, standardisation and Lapita ceramics. In Oceanic Explorations: Lapita and Western Pacific Settlement (S. Bedford, C. Sand, and S. P. Connaughton, eds.):289-299. Canberra: Terra Australis 26, The Australian National University, Pandanus Books.

Clark, G. R. and A. J. Anderson. 2009. Colonisation and culture change in the early prehistory of Fiji. In The Early Prebistory of Fiji (G. R. Clark and A. J. Anderson, eds.):387-418 Canberra: Terra Australis 31, ANU E press.

Clark, G. R. and A. J. Anderson (eds.). 2009. The Early Prebistory of Fiji. Canberra: Terra Australis 31, ANU E press.

DeNiro, M. J. 1985. Post-mortem preservation and alteration of in vivo bone collagen isotope ratios in relation to palaeodietary reconstruction. Nature 317:806-809.

Dickinson, W. R., S. Bedford, and M. Spriggs. 2013. Petrography of temper sands in 112 reconstructed Lapita pottery vessels from Teouma (Efate): Archaeological implications and relations to other Vanuatu tempers. Journal of $\mathrm{Pa}$ cific Archaeology 4(2):1-20.

Duday, H. 1990. Observations ostéologiques et décomposition du cadavre: Sépulture colmatée ou en espace vide. Revue Archéologique du Centre de la France 29(2):193196.

Duday, H. 2009. The Archaeology of the Dead. Lectures in Archaeothanatology. Oxford: Oxbow Books.

Duday, H., P. Courtaud, E. Crubézy, P. Sellier, and A.-M. Tillier. 1990. L'anthropologie "de terrain": Reconnaissance et interprétation de gestes funéraires. Bulletins et Mémoires de la Société d'Antbropologie de Paris 2(3-4): 29-50.

Dupras, T. L. and H. P. Schwarcz. 2001. Strangers in a Strange Land: Stable Isotope Evidence for Human Migration in the Dakhleh Oasis, Egypt. Journal of Archaeological Science 28(11):1199-1208.

Green, R. C. 1963. A suggested revision of the Fiji sequence. Journal of the Polynesian Society 72:235-53.

Haberle, S. G. and A. Chepstow Lusty. 2000. Can climate influence cultural development? A view through time. Environment and History 6:349-369.

Herrscher, E. and G. Le Bras-Goude. 2010. Southern French Neolithic populations: Isotopic evidence for regional specificities in environment and diet. American Journal of Physical Anthropology 141:259-272. 
Hertz, R. 1907. Contribution à une étude sur la représentation collective de la mort. L'Année Sociologique (1905-1906): 48-137.

Horrocks, M. and S. Bedford. 2005. Microfossils of introduced Araceae (aroids) reveal Lapita horticulture in Vanuatu. Archaeology in Oceania 39:67-74.

Horrocks, M. and S. Bedford. 2010. Introduced Dioscorea spp. starch in Lapita and later deposits, Vao Island, Vanuatu. New Zealand Journal of Botany 48:179-183.

Horrocks, M., S. Bedford, and M. Spriggs. 2009. A short note on banana (Musa) phytoliths in Lapita, immediately post-Lapita and modern period archaeological deposits from Vanuatu. Journal of Archaeological Science 36:20482054.

Katzenberg, A. and R. S. Saunders (eds.). 2008. Biological Antbropology of the Human Skeleton, 2nd ed. Hoboken, NJ: John Wiley \& Sons Inc.

Keegan, W. F. and M. J. DeNiro. 1988. Stable carbon and nitrogen-isotope ratios of bone collagen used to study coral-reef and terrestrial components of prehistoric Bahamian diet. American Antiquity 53(2):320-336.

Kinaston, R. L. and H. R. Buckley. 2013. The stable isotope analysis of prehistoric human diet in the Pacific Islands with an emphasis on Lapita. University of Otago studies in Archeology 25:91107.

Kinaston R. L., H. R. Buckley, S. E. Halcrow, M. J. T. Spriggs, S. Bedford, K. Neal, and A. Gray 2009. Investigating foetal and perinatal mortality in prehistoric skeletal samples: a case study from a 3000-year-old Pacific Island cemetery site. Journal of Archaeological Science 36(12):27802787.

Kinaston, R., H. Buckley, F. Valentin, S. Bedford, M. Spriggs, S. Hawkins, and E. Herrscher. 2014. Lapita diet in Remote Oceania: New stable isotope evidence from the 3000-year-old Teouma site, Efate Island, Vanuatu. Plos One 9(3):e90376.

Kirch, P. V. 1984. The Evolution of the Polynesian Chiefdoms. Cambridge: Cambridge University Press.

Kirch, P. V. 1985. Featbered Gods and Fishbooks: An Introduction to Hawaiian Archaeology and Prebistory. Honolulu: University of Hawai'i Press

Kirch, P. V. 2000. On the Road of the Winds: An Archaeological History of the Pacific Islands before European Contact. Berkeley: University of California Press.

Kirch, P. V. 2007. Concluding remarks, methods, measures, and models in Pacific paleodemog- raphy. In The Growth and Collapse of Island Societies (P. V. Kirch and J.-L. Rallu, eds.):326337. Honolulu: University of Hawai'i Press.

Kirch, P. V. 2010. How Chiefs Became Kings. Divine Kingship and the Rise of Archaic States in Ancient Hawai'i. Berkeley: University of California Press.

Leach, B. F., C. J. Quinn, and G. L. Lyon. 1996. A stochastic approach to the reconstruction of prehistoric human diet in the Pacific region from bone isotope signatures. Records of the Museum of New Zealand Te Papa Tongarewa 8:1-54.

Mead, J., D. Steadman, S. Bedford, C. Bell, and M. Spriggs. 2002. New extinct mekosuchine crocodile from Vanuatu, South Pacific. Copeia: 632-641

Morrison, A. E. and D. J. Addison. 2008. Assessing the role of climate change and human predation on marine resources at the Fatu-ma-Futi site, Tutuila Island, American Samoa: An agent based model. Archaeology in Oceania 43:22-34.

Nunn, P., T. Ishimura, W. R. Dickinson, K. Katayama, F. Thomas, R. Kumar, S. Matararaba, J. Davidson, and T. Worthy. 2007. The Lapita occupation at Naitabale, Moturiki Island, central Fiji. Asian Perspectives 46:96-132.

Ortiz A., P. Chambon, M. Molist. 2013. "Funerary bundles" in PPNB at the archaeological site of Tell Halula (middle Euphrates valley, Syria): Analysis of the taphonomic dynamics. Journal of Archaeological Science 40:4150-4161.

Petchey, F., M. Spriggs, F. Leach, M. Seed, C. Sand, M. Pietrusewsky, and K. Anderson. 2011. Testing the human factor: Radiocarbon dating the first peoples of the South Pacific. Journal of Archaeological Science 38(1):29-44.

Phillips, D. L. and J. W. Gregg. 2003. Source partitioning using stable isotopes: Coping with too many sources. Oecologia 136:261-269.

Phillips, D. L. and P. L. Koch. 2002. Incorporating concentration dependence in stable isotope mixing models. Oecologia 130:114-125.

Pietrusewsky, M., J. C. Galipaud, and B. F. Leach. 1998. A skeleton from the Lapita site at Koné, Foué Peninsula, New Caledonia. New Zealand Journal of Archaeology 18(1996):25-74.

Pietrusewsky, M., T. L. Hunt, and R. M. Ikehara-Quebral. 1997. A Lapita skeleton from Waya Island, Fiji. Micronesica 30(2):355388.

Reepmeyer, C. and G. Clark. 2010. Post-colonial interaction between Vanuatu and Fiji reconsidered: The re-analysis of obsidian from Lakeba Island, Fiji. Archaeometry 52(1):1-18.

Reepmeyer C., M. Spriggs, S. Bedford, and W. Ambrose. 2011. Provenance and technology of 
lithic artifacts from the Teouma Lapita site, Vanuatu. Asian Perspectives 49(1):205-225.

Sand, C. 2010. Lapita Calédonien. Paris: Société des Océanistes, Travaux et Documents océanistes 2.

Sand C., J. Bolé, and A. Ouétcho. 2011. A revision of New Caledonia's ceramic sequence.Journal of Pacific Archaeology, 2(1):56-68.

Schoeninger, M. J., 2010. Diet reconstruction and ecology using stable isotope ratios. In A Companion to Biological Antbropology (C. S. Larsen ed.):445-464. Chichester: WileyBlackwell.

Schroeder, S. 2001. Secondary disposal of the dead: Cross-cultural codes. World Cultures 12(1):77-93.

Schwarcz, H. P., T. L. Dupras, and S. I. Fairgrieve. 1999. 15N Enrichment in the Sahara: In Search of a Global Relationship. Journal of Archaeological Science 26(6):629-636.

Scott, R., H. Buckley, M. Spriggs, F. Valentin, and S. Bedford. 2010. Identification of the first reported Lapita cremation in the Pacific Islands using archaeological, forensic and contemporary burning evidence. Journal of Archaeological Science 37:901-909.

Sealy, J. C., N. J. van der Merwe, J. A. Lee-Thorp, and J. L. Lanham. 1987. Nitrogen isotopic ecology in Southern Africa: implications for environmental and dietary tracing. Geochimica et Cosmochimica Acta 51:2707-2717.

Spriggs, M. 1997. The Island Melanesians. Oxford: Blackwell.

Spriggs, M. 2003. Post-Lapita evolutions in Island Melanesia. In Pacific Archaeology: Assessments and Prospects. Proceedings of the International Conference for the 50th Anniversary of the first Lapita Excavation, Koné-Nouméa 2002 (C. Sand, ed.):213-220. Nouméa: Museum of New Caledonia. Les Cahiers de L'Archéologie en Nouvelle-Calédonie 15.

Spriggs, M. 2004. Is there Life after Lapita, and Do You Remember the 60s? The Post-Lapita sequences of the Western Pacific. In $\mathrm{APa}$ cific Odyssey: Archaeology and Antbropology in the Western Pacific. Papers in Honour of Jim Specht (V. Attenbrow, and R. Fullager, eds.):139-144. Sydney: Australian Museum. Records of the Australian Museum, Supplement 29.

Steadman, D. W. 2006. Extinction and Biogeograpby of Tropical Pacific Birds. Chicago: University of Chicago Press.

Storey, A. A., M. Spriggs, S. Bedford, S. Hawkins, J. H. Robins, L. Huynen, and E. MatisooSmith. 2010. Mitochondrial DNA from 3000- year old chickens at the Teouma site, Vanuatu. Journal of Archaeological Science 37:24592468.

Summerhayes, G. 2007. The rise and transformation of Lapita in the Bismarck Archipelago. In From Soutbeast Asia to the Pacific. Archaeological perspectives on the Austronesian expansion and the Lapita Cultural Complex (S. Chiu and C. Sand, eds.):141-169. Taipei: Centre for Archaeological Studies, Academia Sinica.

Summerhayes, G. 2009. Obsidian networks patterns in Melanesia-Sources, characterization and distribution. Bulletin of the Indo-Pacific Prebistory Association 29:109124.

Valentin, F. 2003. Human skeletons recovered in the site of Lapita at Koné (New Caledonia). In Pacific Archaeology Assessments and Prospects (C. Sand, ed.):285-293. Nouméa: Les Cahiers de l'archéologie en Nouvelle-Calédonie 15.

Valentin, F., S. Bedford, H. Buckley, and M. Spriggs. 2010a. Inhumations, exhumations and bone treatment in a Lapita community as reflected at the Teouma burial ground, Vanuatu. Journal of Island and Coastal Archaeology 5(2):212-235.

Valentin, F., H. Buckley, E. Herrscher, R. Kinaston, S. Bedford, M. Spriggs, S. Hawkins, and K. Neal. 2010b. Lapita subsistence strategies and food consumption patterns in the community of Teouma (Efate, Vanuatu).Journal of Archaeological Science 37:1820-1829.

Valentin, F., A. Ouetcho, and J. Bolé. 2005. Rapport numéro 2 sur l'étude paléoantbropologique des ossements bumains Lapita découverts sur le site WKOO13B (Foué, Koné) à la suite du cyclone Erica, Résultat du deuxième décapage de la structure. Report on file. Nouméa: Département Archéologie du Service des Musées et du Patrimoine de Nouvelle-Calédonie.

Valentin, F., M. Spriggs, S. Bedford, and H. Buckley. 2009. Une analyse diachronique des pratiques funéraires préhistoriques du centre du Vanuatu. Journal de la Société des Océanistes 128(1):39-52.

Valentin, F., M. Spriggs, S. Bedford, and H. Buckley. 2011. Vanuatu mortuary practices over three millennia: Lapita to the early European contact period.Journal of Pacific Archaeology 2(2):49-65.

van Klinken, G. J. 1999. Bone collagen quality indicators for palaeodietary and radiocarbon measurements. Journal of Archaeological Science 26:687-695. 
White, A. W., T.H. Worthy, S. Hawkins, S. Bedford, and M. Spriggs. 2010. Megafaunal meiolaniid horned turtles survived until early human settlement in Vanuatu, Southwest Pacific. Proceedings of the National Academy of Sciences, USA 107(35):15512-15516.
Wirrmann, D., S. H. Eagar, M. A. Harper, E. Leroy, and A.-M. Sémah. 2011. First insights into midHolocene environmental change in central Vanuatu inferred from a terrestrial record from Emaotfer Swamp, Efate Island. Quaternary Science Reviews 30:3908-3924. 